\title{
Development of Assessment Instrument for Social Care Character in Civic Education Course at Universitas Negeri Semarang
}

\author{
Sunarto Sunarto*, Tijan Tijan, Tutik Wijayanti, and Eta Yuni Lestari \\ Program Studi PPKn \\ Universitas Negeri Semarang \\ Semarang, Indonesia \\ *sunarto@mail.unnes.ac.id
}

\begin{abstract}
This study aims to develop a reliable and effective character assessment instrument in the Civic Education course. The research method used is research and development $(R \& D)$ method that aims to produce the product and test the effectiveness of the product through 6 stages of research. The results achieved in this research that is known some problems in making the instrument of social care character assessment experienced by lecturers. Based on the existing problems, the instrument is developed to be validated by experts. Instruments that have been validated then being tested in the classroom. The results of trials analysis are three points of observation have very low degree of validity, one item has low validity, two items have medium validity, eight items have high validity and six items of observation have very high validity. Meanwhile, for instrument reliability based on analysis with SPSS has a high level of reliability, that is equal to 0.765 .
\end{abstract}

Keywords-assesment instrument; civic education; social caring character

\section{INTRODUCTION}

National Education serves to develop the ability and form the character and civilization of a dignified nation in order to educate the nation's life [1]. Education is one of the government's efforts to shape the character of a good nation in Indonesia. Character education is currently considered as one of the strategic efforts to form the Golden Generation of Indonesia [2].

The big problem who faced is the decline in the character value of Indonesians. Currently, at least two main problems related to the Indonesian education activities, firstly the low quality of process and educational outcomes, both the weak character of the nation as education products that have been implemented [3]. Education plays an important role, especially schools and colleges to build the character of the nation for the young generation. This is evidenced by the character crisis that is getting away from Pancasila values that are felt increasingly apparent. The character crisis occurs in the young generation as evidenced by the higher levels of juvenile delinquency. Violations of the norms of the younger generation are increasingly diverse, such as drugs, free sex, smoking, liquor, fights, and other juvenile delinquency issues [4].
The purpose of character education is to raise children as people with broad insight and have caring character [5]. During this time, character education in college is only charged to subjects related to personality, such as Religious Education, Citizenship Education, and Counseling Guidance [6]. Successful civic education will foster intelligent, responsible attitude of students with behaviors (1) faithful and devoted to God Almighty and living the values of the nation's philosophy; (2) noble character, discipline; (3) rational, dynamic, and understanding rights and obligations as citizens; (4) are professionals imbued with the awareness of state defense; and (5) utilizing science and technology and art for the benefit of humanity, nation and state [7].

Character education is a national movement that creates schools and colleges that fosters the ethics of the young generation who are responsible and have a caring character [8]. Caring character is important to make student able to collaborate on solving environmental problems and it does not automatically naturally [9]. This commitment needs to be realized through learning process inside or outside the classroom. Problems that occur, just a few lecturer at the Faculty of Social Sciences (FIS) who do the assessment of social care characters using standardized assessment instrument. During this time, the assessment of students is still limited to the cognitive aspects obtained from the results of written examinations, while the assessment of the affective and psychomotor aspects are still rarely done. Assessment is an attempt to find out how high the success rate of educational activities [10]. Assessment in learning is a decision making value of success in a learning through benchmarking with applicable provisions. Assessment is also a measurement of the success of educators in the learning process. Assessment aims to ensure that the process and performance achieved are in accordance with the plan and objectives [11].

The results of observations that have been done, indicate that there are still many lecturers at the Faculty of Social Sciences in assessing the character of social care only through observation. Assessment made with instantaneous observation makes the lecturer has not been able to assess objectively so that the learners' learning outcomes can not be known with certainty [12]. objectivity in assessing student learning 
outcomes can not be counted because the lecturer only judge by estimate only, so that the data are not valid. In order to assess the character of social care can be accounted for, it is necessary to develop the instrument of social care character assessment on the subject at the Faculty of Social Sciences. One of the important subjects in character development is the subject of Civic Education, this course has a strategic role in preparing citizens who are aware of their rights and obligations, care about the survival of society, nation and state [7].

This research was conducted for the development of social care character assessment instrument in the course of Civic Education at Universitas Negeri Semarang. This study aims to (1) know the process of developing a social character assessment instrument on the subject of Civic Education at Universitas Negeri Semarang; (2) obtain the result of developing a valid social character assessment instrument on the subject of Civic Education at Universitas Negeri Semarang; (3) to know the reliability of the result of development of social care character assessment instrument on the subject of Civic Education at Universitas Negeri Semarang.

\section{RESEARCH METHOD}

This research is a quantitative research with development method (R\&D) which produces product in the form of social care character assessment instrument in civic education course, with stages analyzing potential and problem, data collection, product design, design validation, design revision, and product trial. This research was conducted with the locus of Semarang city precisely at Universitas Negeri Semarang. The collection of data and information in this research is carried out in various ways and techniques accordingly. Technique of collecting data and information is done through observation and interview. The data of the research results are then tested to analyze the validity and reliability of the instrument. In this study, the determination of content validity using expert judgment, while the determination of construct validity for the social care character assessment instrument is analyzed with the help of SPSS and using the following Product Moment Correlation formula.

\section{RESUlT AND DisCUSSION}

Based on research at Universitas Negeri Semarang who became the research locus, the research result as follows. The development of a social care character appraisal instrument in the civic education course begins by identifying the problems experienced by the lecturer in carrying out the characterization of social care character. Based on the results of initial identification, it is found that most lecturers have conducted the assessment of social care characters by (1) momentary observations conducted during the learning process, (2) assigning practical tasks and then doing observations without instruments, (3) using questionnaires.

The difficulties in the implementation of social care character assessment belongs to (1) there is no clear assessment indicator, (2) lecturers have not been able to prepare non-test assessment instruments, (3) the absence of the assessment module as well as examples of social care character assessment instruments that are standardized and tested for their effectiveness and practicality. This is in line with that delivered by Hidayati [13] the implementation of character education has not been so far done with clear standards so that the results can not be measured its effectiveness and practicality. Based on the results of initial identification, the next step is designing an instrument of social care character assessment in the course of Civic Education based on the indicator of learning activities. The instruments already designed are then discussed and validated by the expert. The next step in the development of the social care character assessment instrument is to test the product. Product trials are conducted by integrating assessment during the learning process. Instrument assessment was developed based on the learning stage by using role playing method on democracy material and being tested on 40 students in one class.

Assessment of social care characters implemented by observing student activities during the learning process takes place. The results of these observations are then included in the assessment table by analyzing the activities of students in the implementation of learning in the classroom. Observation and recording of student activities is done from the preparation, selection of participants / players, the selection of observers, arrangement of places, to the implementation of role play and evaluation activities. As for the role that is played is 1). Presidential and vice-presidential debates moderated by 2) voting, where the student performs activities in the general election, 3) the vote counting process to decide the winner.

From each student activity, the lecturer performs the assessment by observing and recording every activities shown by the students based on the instruments that have been designed. For example, student activities that show a social attitude such as the attitude of students who helped arrange the place to play the role voluntarily without being asked by lecturers or other colleagues of students. From the attitude shown by the students, the lecturer can record in the assessment instrument table. Similarly, for other activities, of any attitudes indicated by the student, may be recorded in the appraisal table. After all the classroom learning process has been completed, the observed results in the appraisal table can be analyzed using statistical analysis to determine the validity and reliability of the assessment instruments already tested.

Second, calculate the validity of the social care character assessment instrument on the Civic Education Course. Based on instrument validity test by using SPSS, from twenty items of observation that have been compiled data as follows. The validity of item 1 is 0.714 ; item 2 the validity is 0.819 ; item 3 is 0.087 ; item 4 is 0.041 ; item 5 is 0.593 ; item 6 is 0.421 ; item 7 is 0.621 ; item 8 is 0.640 ; item 9 is 0.179 ; item 10 is 0.804 ; item 11 is 0.362 ; item 12 is 0.747 ; item 13 is 0.836 ; item 14 is 0.789 ; item 15 is 0.861 ; item 16 is 0.758 ; item 17 is 0.908 ; item 18 is 0.859 ; item 19 is 0.732 ; item 20 is 0.705 .

Based on the validity test that has been done, there are three items of observation that have very low degree of validity, that is on items of observation no 3, 4 and 9 with validity value less than 0.20 . Item Number 11 has a low degree of validity because its validity value is more than 0.20 and less than 0.40 . The points of observation of numbers 5 and 6 have a moderate 
degree of validity because the validity values are more than 0.40 and less than 0.60 whereas in items $1.17,8,12,14,16,19$ and 20 have a high degree of validity because of the value validity of more than 0.60 and less than 0.80 . Item $2,10,13$, 15,17 and 18 have very high degree of validity because the validity value is more than 0.80 and less than 1.00 . From the existing data indicates that the instrument of assessment of social care characters that have been developed have varying levels of validity.

In the assessment of social caring character, of the 20 items of observation of social care characters, 3 of them (item 3, 4, and 9) are not valid [14] because they have validity value under $\mathrm{r}$ table. Therefore, for grain observation of social caring character that can be used as much as 17 points. While 3 items of invalidity are discarded.

The next step is reliability test instrument of social care character assessment using SPSS, the result were obtained is 0.765 . Based on the criteria of reliability according to Arikunto [14] can be concluded that the point of observation of social care characters reliable because the reliability value above 0.60 . Thus, it can be concluded that the value of reliability in the observation of social care character has a criterion of high degree of reliability because the value of reliability is more than 0.60 and less than 0.80 . From the data, the assessment instrument of social care character in the civic education course that has been developed can be used because it has good validity and reliability.

\section{CONCLUSION}

From the results of the study, it was concluded that the development of social care character assessment instrument begins by identifying the problem. The identification is related to the assessment instrument by the lecturer in assessing the social caring character of the civic education course. Based on the results of initial identification, it is known that the lecturers of the subjects of Civic Education found a difficulties in conducting the assessment of social care characters. From this preliminary data, the further research design the social care character assessment instrument in the civic education course to be further validated by the expert. After the instrument is declared valid by the expert, the next step is trial product tested on 40 students in a class by using the method of role playing. Based on the validity test it can be concluded that there are three points of observation that have very low degree of validity, that is on item 3,4 and 9 with points of validity less than 0.20 . Item Number 11 has a low degree of validity because its validity value is more than 0.20 and less than 0.40 . The points of observation of numbers 5 and 6 have a moderate degree of validity because their validity values are more than 0.40 and less than 0.60 whereas in items $1.17,8,12,14,16,19$ and 20 have a high degree of validity because of the value validity of more than 0.60 and less than 0.80 . Item $2,10,13$, 15,17 and 18 have very high degree of validity because the validity value is more than 0.80 and less than 1.00 . (3) the reliability of the items of social caring character has a high degree of reliability criteria because the reliability value is more than 0.60 and less than 0.80 .

\section{REFERENCES}

[1] UU Sisdiknas, No. 20 Year 2003

[2] Dewiyanti, S. M.J and Sagirani, Tri. 2014. Inculcation Method of Character Education Based on Personality Types Classification in Realizing Indonesia Golden Generation. International Journal of Evaluation and Research in Education (IJERE). Vol.3, No.2. Hal 91-94.

[3] Abidin, Jonah. 2012. The Authentic Assessment Model in Reading Learning The understanding of character-oriented education. Character Education Journal 2nd edition of 2012

[4] Suprayogi, et al. 2017. Character Education Based on Pancasila Values through Citizenship Education Learning. In Proceedings of National Seminar on "Actualization of Pancasila Education and Citizenship Education to strengthen the joints of national life" AP3KNI of Central Java Province November 11, 2017.

[5] Turan, Fethi and Ulutas, Ilkay. 2016. Using Storybooks as a Character Education Tools. Journal of Education and Practice. Vol.7, No.15.

[6] Sutijan et al. 2015. Development of Integrated Character Education Assessment Instrument. http://jurnal.fkip.uns.ac.id/index.php/paedagogia/article/view/7517 accessed on Wednesday, April 5, 2017.

[7] Sunarto, et al. 2016. Citizenship Education. Semarang: Unnes Press

[8] Pala, Aynur. 2011. The Need for Character Education. International Journal Of Social Sciences And Humanity Studies. Volum 3 No.2. Hal 23-32. ISSN: 1309-8063

[9] Binkley, Marilyn et al. (2012). Defining Twenty-First Century Skills. In Grifin, P., Care, E., \& McGaw, B (eds). Assessment and Teaching of 21 st Century Skills (pp.17-66). London: Springer.

[10] Arikunto, Suharsimi. 2002. Research Procedures Approach A Practice. Jakarta: Rineka Cipta.

[11] Mulyasa, E. (2013). Uji kompetensi dan Penilaian Kinerja guru. Bandung: PT Remaja Rosdakarya.

[12] Wijayanti, Tutik. 2016. Development of Learning Assessment Instrument. Integralistic Journal. June 2016 edition.

[13] Hidayati, dkk. 2014. The Development Of Character Education Curriculum For Elementary Student In West Sumatera. International Journal of Education and Research. Vol. 2 No. 6

[14] Arikunto, S. (2003). Prosedur Penelitian: Suatu Pendekatan Praktek. Edisi Revisi V. Jakarta: Rineka Cipta. 